\title{
THE TER, A MEDITERRANEAN RIVER SYSTEM IN SPAIN
}

\author{
S. Sabater, H. Guasch, E. Martí, J. Armengol, M. Vila and F. Sabater \\ Departament d'Ecologia, Universitat de Barcelona, Avgda Diagonal 645, 08028 Barcelona, Spain.
}

Keywords: River, Mediterranean, Water characteristics, Biological communities, Primary production, Nutrient dynamics.

\begin{abstract}
Irregular hydrology and human influences are common features in the Mediterranean river systems in Spain. The two affect both the water characteristics and the distributional patterns of the organisms. Current research on functional aspects of undisturbed tributaries is ultimately directed to give light to the behaviour of Mediterranean rivers. Analysis of nutrient dynamics and epilithon metabolism is being performed in two low-order tributaries under different environmental conditions (essentially light and substrata). Results are discussed with respect to the special character of the Mediterranean rivers.
\end{abstract}

\section{CLIMATE AND MAN, INTERACTING FACTORS IN SHAPING THE TER.}

The Mediterranean region is one of the most densely populated and industrially developed areas in Spain. Most of the rivers in this region, including the Ter, reveal many of the anthropogenic disturbances derived from the use of their waters (domestic, agricultural and industrial water supplies, power generation, waste disposal, recreation...) which have affected the river basins for centuries.

Human influence on the Ter started in the Middle Ages with iron industries (catalan "fargues"), which caused great deforestation in large areas. During the Industrial Revolution, cotton mills and paper mills proliferated along its banks, attracted by the quality of its water. An inheritance of this period is the presence of small dams and channels directing the water to the production of hydraulic power. Regulation of the Ter was completed during the 1950's by the construction of two large reservoirs in the middle stretch of the river (fig. 1). Since then, the high development of industrial facilities and, in general, the unplanned growth of urban centers have caused the affluence of enormous sewage inputs to the river. Human pressure on the river is diverse and has increased in recent times. Intensive farming, urban development and industry depend on its waters. Up to now the Ter remains undisturbed only in some of its first and second order tributaries.

In addition to this considerable anthropogenic impact, fluctuations in water discharge due to the Mediterranean climate creates variable conditions in the river. Summer is usually very dry period while high discharge (due to heavy rain) is common in autumn. The location of the Ter headwaters in the Pyrenees, where the discharge pattern is strongly regulated by snow accumulation and melting means lower flow in winter and subsequent increase in spring.

Although the annual average discharge is $554,6 \pm 36$ $\mathrm{Hm}^{3}$, this value varies considerably in successive years (fig. 2). This is a common feature in the Mediterranean region. The water discharge in the Ter shows a very seasonal cycle, but in practice climatic events introduce a source of varia-

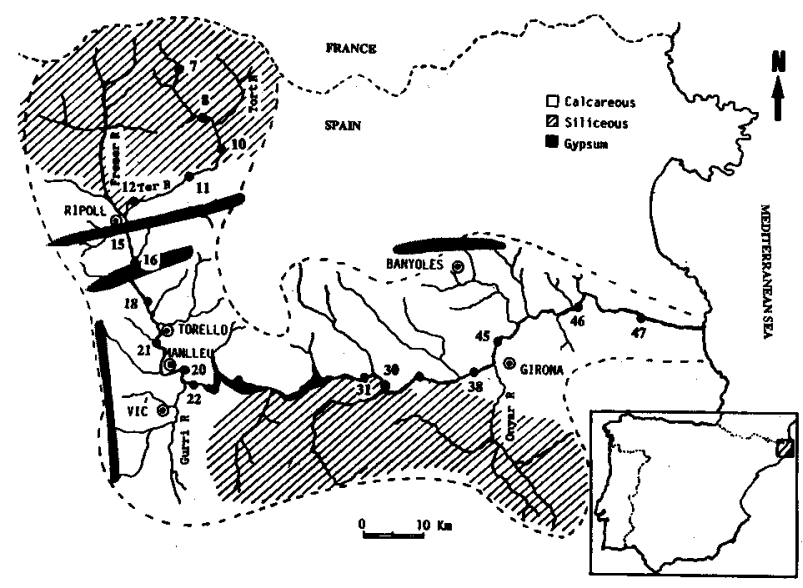

Figure 1. Location of the studied sampling-points in the Ter River. The main geological features of the basin, and towns with more than 10,000 inhabitants are shown. 
bility in runoffs (ARMENGOL et al., 1991). Short fluctuations of 3,6 and 12 months determine the seasonality of the annual cycle. Annual fluctuations have periods of 5.5, 8.6, 10.1 and 11.7 years. These longer term fluctuations can be considered as an expression of cycles of 7 and 11 years which are characteristic of many climatic events in the Mediterranean region. The state of the water and the biological communities in the river are obviously affected by this temporal varition.

\section{PHYSIOGRAPHICAL CHARACTERISTICS OF THE TER.}

The River Ter drains about $3,010 \mathrm{~km}^{2}$ of the north part of Catalonia (NE Spain). It rises at $2,400 \mathrm{~m}$ a.s.l. in the Pyrenees and flows $208 \mathrm{~km}$ down to the Mediterranean sea. During its course it receives a large number of tributaries. The largest in the upper part is the river Freser (4th order). The upper Ter and Freser basins receive a high number of small streams feeding in the Pyrenees. In its middle stretch, the Ter receives small 2 nd to 3 rd order streams, coming from middle-mountain basins. Three reservoirs (Sau, Susqueda and El Pasteral; joint capacity of $0.402 \mathrm{~km}^{3}$; average residence time of the water of 117,143 and 1.7 days respectively) are also located in this stretch (fig. 1). The reservoirs exert a direct influence on the lower part of the river (PUIG et al., 1987). Before it reaches the sea the Ter receives the Onyar River, a 4th. order stream, which has a marked mediterranean regime, but does not highly alter the Ter hydrography. When the Ter flows out into the Mediterranean sea, it is a 5 th order stream.

The middle and low parts of the main stretch of the river, including a large number of tributaries, drain calcareous areas. However, the Ter headwaters and some of the tributaries in the middle stretch flow over granites and slates, while a few tributaries drain areas which are rich in gypsum (fig. 1).

\section{WATER CHARACTERISTICS AND SEDIMENT TRANSPORT}

In the Ter basin the high diversity of land uses, vegetation cover and soil types cause differential influences on the physical and chemical features of the water.

The Ter waters are rich in $\mathrm{Ca}\left(\mathrm{HCO}_{3}\right)_{2}$ (SABATER, 1988). Most of its basins have alkaline-earth bicarbonate waters: hydrocarbonate represents $63 \%$ of the total anions and calcium $60 \%$ of the total cations. Other ions reach relevant concentrations in particular places along the river: sulphate constitutes on the average $24 \%$ and chloride only 13 $\%$ of the total anions. These last two anions are only abundant in particular parts of the river. Water conductivity rises from less than $100 \mu \mathrm{sm}^{-1}$ in the headwaters to more than $1000 \mu \mathrm{s} \mathrm{cm}^{-1}$ in the lower reaches. Such a general increase may be related both to the rock weathering and to human activity, this latter leading to particular increases in chloride, sodium and potassium.

Nutrient concentrations in the Ter waters are mainly related to land use. This defines important spatial variations throughout the basin. On the other hand, temporal variations in nutrient concentrations are highly dependent on hydrological features. Both organic and inorganic forms of dissolved phosphate decrease during high discharge, while the particulate form exhibits a slight increase in such periods (fig. 3b). During high water levels there is an important increase in nitrate whereas ammonium and nitrite decrease. Ammonium dynamics is only partially regulated by the water discharge; increases are related to pollutant inflows. The organic forms of nitrogen predominate during high discharge (fig. 3a).

In the upper part of the river where the bedrock is siliceous and human activity is low, the content of total dissolved solids (TDS) is very low, usually less than $20 \mathrm{mg}^{-1}$. TDS values are high in sites upstream from the reservoirs (up to $80 \mathrm{mg} \mathrm{l}^{-1}$ ). TDS reaches extremely high values (up to 600 $\mathrm{mg} \mathrm{l}^{-1}$ ) in a polluted tributary which enters the river at the jonction with the reservoirs. Reservoirs act as decanting lagoons; TDS at their outflow has been reduced to $10 \mathrm{mg} \mathrm{l}^{-1}$. Values of TDS in the tributaries vary according to their geochemical features (siliceous vs. calcareous) and the extent of forest cover.

The Ter River drains unforested areas which are interspersed among well forested areas. The basins of the Ter

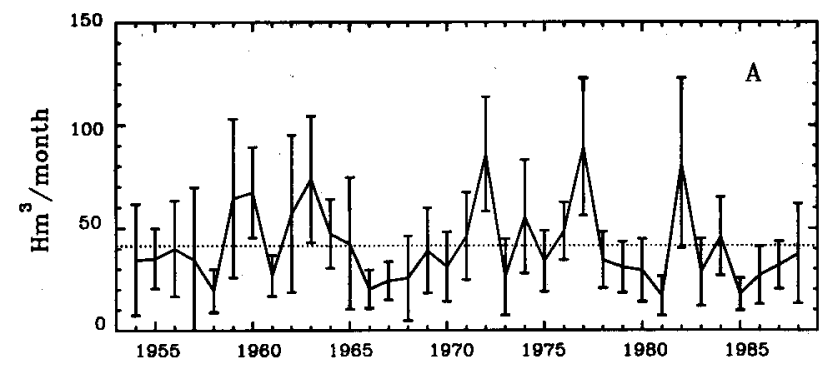

Figure 2. Annual average discharges during the period 1954 to 1988. The amplitude of the $95 \%$ confidence intervals evidences the importance of the seasonal variations. 
headwater and those of some small tributaries possess abundant riparian forests of deciduous trees. These zones act as a source of particulate organic matter for the heterotrophic communities of the river (recorded values of Coarse Particulate Organic Matter, CPOM, of $1.78 \mathrm{~g} \mathrm{~m}^{-3}$ in winter). The irregularity in land use is evidenced in the spatial distribution of Fine Particulate Organic Matter (FPOM). Highest values during winter $\left(0.014 \mathrm{~g} \mathrm{~m}^{-3}\right)$ were recorded at sites downstream from the reservoirs. Such a peak may be related to the the high amount of autochthonous organic matter (mainly filamentous diatoms), which can balance the effect of the reservoirs.

\section{ECOLOGICAL STRUCTURE OF BIOLOGICAL COMMUNITIES}

\section{Primary producers.}

Macrophytes (bryophytes and higher plants) conform an important part of the primary producers in some zones of the river. Briophytes mainly occupy the higher, headwater stretches, while higher plants tend to be established in the lower parts of the river. PEÑUELAS and SABATER (1987) outlined up to five groups of macrophytes according to the similarities of the assemblages.

Phytoplankton development is limited to sparse small pools in the middle stretch of the river and in the river mouth (SABATER, 1990a). The short length of the river and its irregular water regime implies a short residence time of the water, which determines a poor growth of phytoplankton. Phytoplankton assemblages contain a high number of drifting organisms. Among the euplankters, Centric diatoms are particularly scarce, while green algae (Chlorococcales) account for the highest numbers. Cell densities are usually high, and ranged from 9,000 to 12,000 cells ml-1 in winter and spring, to up to 50,000 in summer during 1984 to 1986 (SABATER, 1990a). This situation is different from that observed in larger mediterranean rivers (SABATER \& MUÑOZ, 1990).

The dominant primary producers throughout the river are the benthic algae (mainly epilithic forms) and among them the diatoms. It is possible to outline up to five groups of sites according to the diatom communities inhabiting the river basin (fig. 4). The average biomass (as chlorophyll- $a$ concentrations) for each group is also indicated in this figure.

The composition and abundance of benthic algal assemblages are related to the changing environmental features of
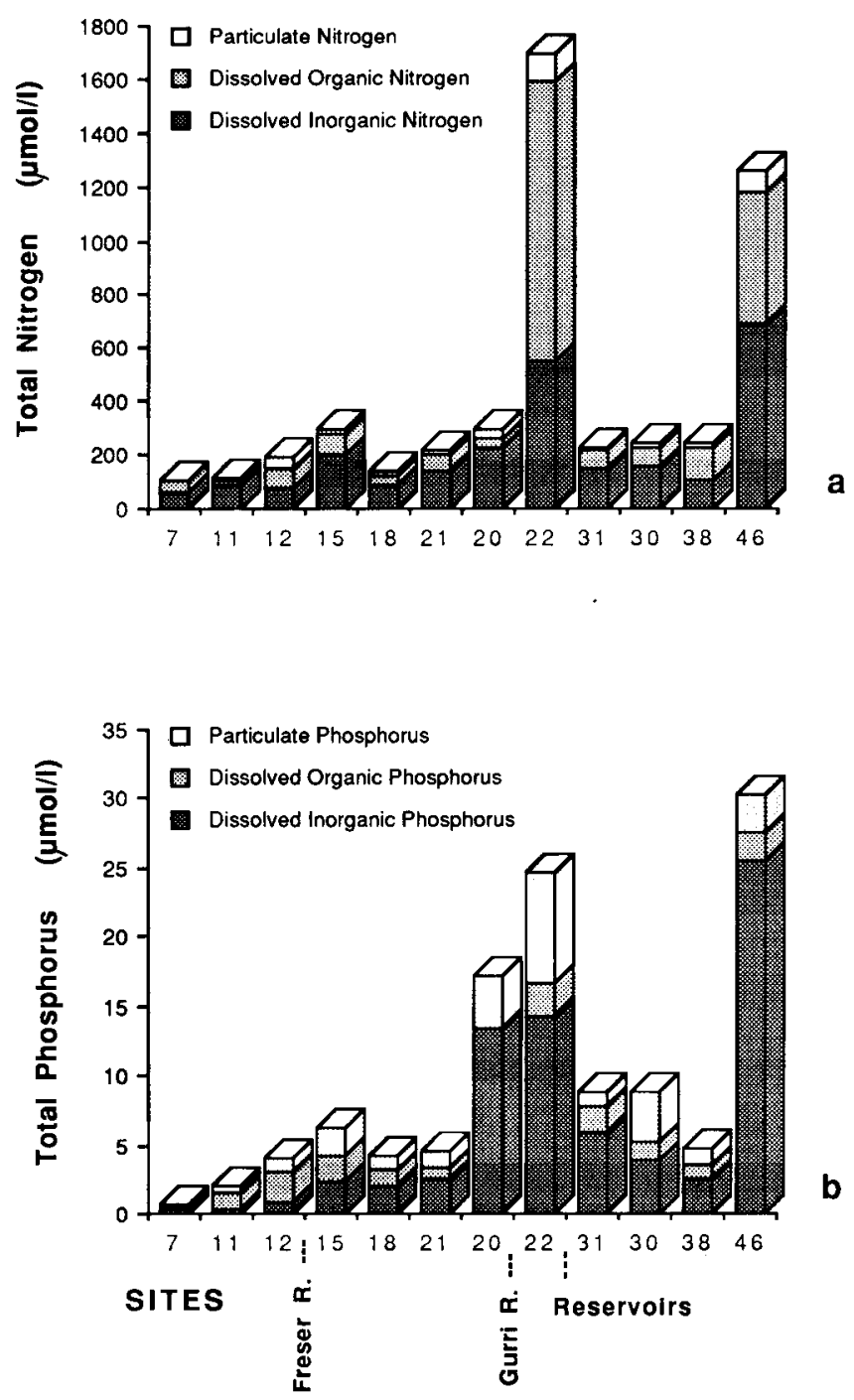

Figure 3. Spatial dynamics of particulate and dissolved forms of (a) nitrogen and (b) phosphorus along the main axis of the river Ter. Data are annual means for the period 1990-1991.

the river. This has been intensively explored in the Ter (SABATER, 1990b; SABATER \& SABATER, 1988; SABATER et al., 1988) with the help of multivariate statistical analyses. The increase in water mineral content downstream and the nutrient concentrations have repeatedly appeared to be the two main factors influencing the structure of algal assemblages. The location of the reservoirs, receiving abundant sewage inputs, favours a change of the water characteristics down to the middle stretch of the river and, correspondingly, a different algal community.

The algal biomass distribution (as chlorophyll-a) is also affected by water chemistry and discharge. These factors 
interact with the natural dynamics of the photosynthesis of the benthic algae (SABATER, 1989). Spatial differences in chl- $a$ along the river are higher in summer than in spring (SABATER \& SABATER, 1991), the two periods of highest production. Differences in discharge, associated with the Mediterranean climate (high in spring, reduced in summer), directly affect the algal communities (scouring in spring, accumulation in summer). Moreover, discharge can also contribute to the pollution-related patchy distribution of nutrients along the river, which can favour local increases in benthic algal biomass in summer.

\section{Secondary producers.}

Macroinvertebrate assemblages in the Ter are affected by similar environmental factors to those affecting the algal communities. The longitudinal organization of the macroinvertebrate guilds is according to the type of food available, but is altered by the pollution of the waters. This ordination is also affected by the reservoirs, which modify water conditions (PUIG et al., 1987). Gathering-collectors and shredders are dominant in the headwaters. The invertebrate predators are more common in this part of the river. Filter-collectors are dominant in the headwater sites only when influenced by anthropogenic activities, with a lower proportion of grazers and scrapers. The macroinvertebrate which inhabit the middle stretch of the river are mainly grazers and filter-feeders, while the collector-gatherers become reduced in comparison with the upper stream zones.

The community inhabiting below the reservoirs is made up of large populations of benthic invertebrates feeding upon nutrient rich seston (ARMITAGE, 1984). Algae, mosses and vascular plants, which are abundant in this stretch of the river, may be fed upon directly or through breakdown and decomposition, while the release of detritus particles becomes a food source for filter-feeders

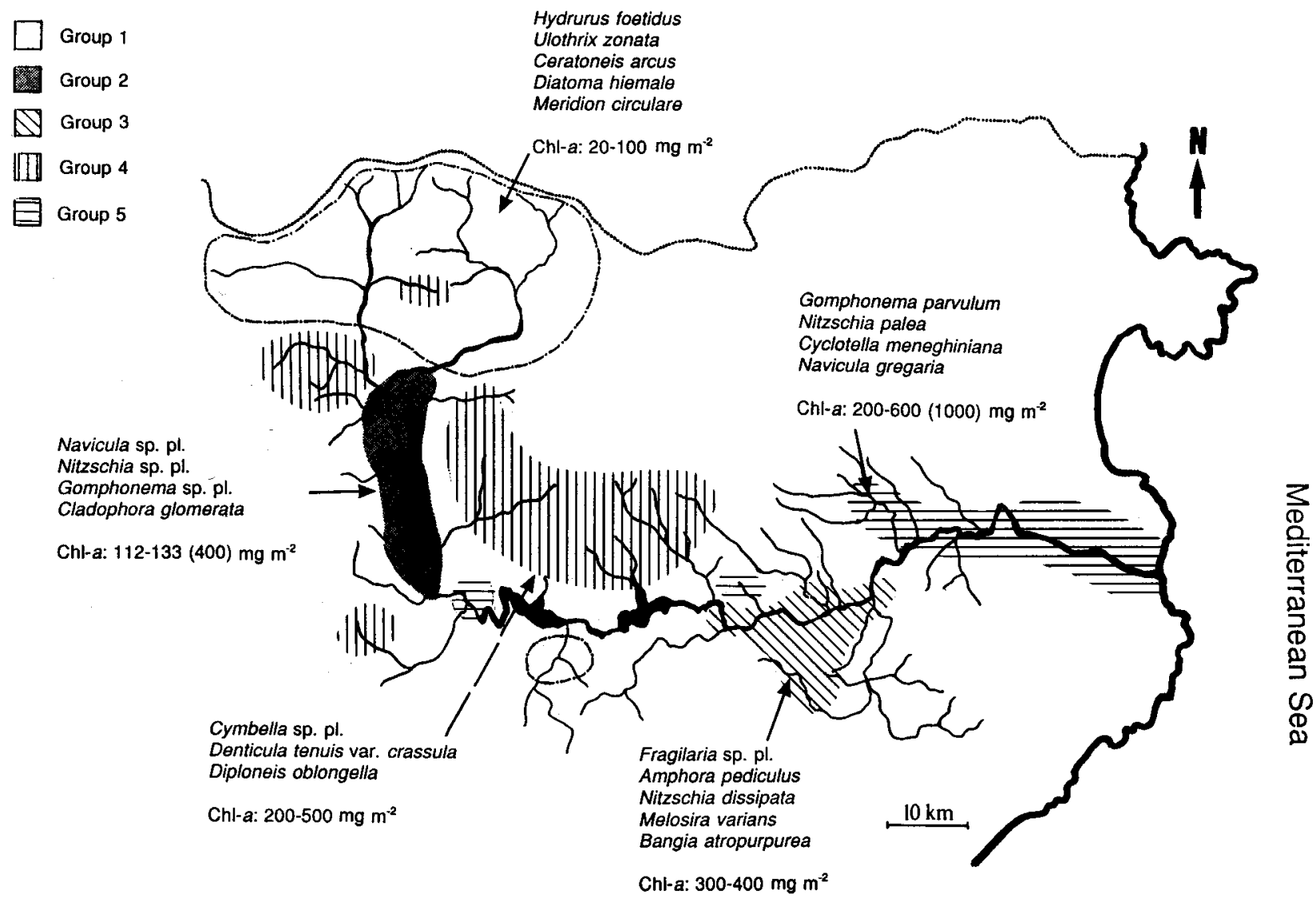

Figure 4. Representation of the five groups of sampling stations according to their similarities in the diatom assemblages. The most characteristic species in every group are listed. Usual values of benthic algae biomass (in $\mathrm{mg}$ of chl-a $\mathrm{m}-2$ ) during the period $1982-1983$ are also indicated. 
(WALLACE \& MERRITT, 1980), or may be deposited into the hyporheic zone where they will provide a nutrient-rich habitat for the hyporheos community (SABATER \& VILA, 1990). The most abundant species within this group are filter-feeding tricoptera which depend on epilimnial suspended matter (WARD \& STANFORD, 1979).

\section{Hyporheos.}

The hyporheic fauna in the Ter River is dominated by insects, (particularly Chironomidae), Crustacea and Oligochaeta. The different proportion among groups of taxa at each site suggests a relationship between hyporheos requirements and physicochemical features in interstitial waters (SABATER,1987; SABATER \& DE MANUEL, 1988). Crustacea, mainly Harpacticoida and Cyclopoida species, are abundant in the interstitial sites of the headwaters. The Isopoda Proasellus phreaticus and Microcharon margalefi were first described from these sites (SABATER \& DE MANUEL, 1988). Ostracoda and Chydoridae become more abundant in clean calcareous tributaries. In sites located further downstream, the occurrence and abundance of these different crustacean groups decrease in number of individuals and taxa. One reason for this is that inputs of fine particulate organic matter coming from anthropogenic activities, cause clogging of the superficial layer of sediments, thus decreasing the oxygen content noticeably. Only some animal groups, such as Nematoda and Oligochaeta, can resist these adverse conditions. In sites strongly affected by pollution there is a striking decrease in interstitial fauna density which, in the worst case, is absent.

In sites below the reservoirs, the interstitial environment is not subjected to a such physical stress. In comparison to upstream sites, the number of Crustacean species and other groups of meio-fauna (e.g., Rotifera, Tardigrada, and hydracnellid mites) become more abundant and persistent in time. However, the most abundant interstitial animal groups occurring below the reservoirs are cyclopoids, oligochaets and chyronomids. This fauna feeds on the fine particulate organic matter accumulated in the sandy-gravel matrix.

\section{CURRENT RESEARCH IN THE RIVER TER.}

\section{Production of epilithic communities in undisturbed tributaries.}

Measurement of oxygen production and respiration of epilithic communities is in progress in two small tributaries of the river Ter. Recirculating light and dark metabolism chambers placed in situ (BOTT et al., 1978) are being used to study the oxygen and carbon dioxide metabolism of two streams of similar geomorphological and physical features (2nd order, low nutrient content of the waters) but of different geology. A phtosynthetic quotient of ca. 0.4 has been calculated for the epilithic community in the two streams, and used to convert oxygen data tocarxbon units.

The first river, La Solana, is calcareous, colonized by carbonate crusts of filamentous cyanobacteria (SABATER 1989). Net daily metabolism (NDM) during 1990 - 1991 was of 0.69-0.73 $\mathrm{g} \mathrm{C} \mathrm{m}^{-2} \mathrm{day}^{-1}$ during summer and autumn and $0.11 \mathrm{~g} \mathrm{C} \mathrm{m}^{-2} \mathrm{day}^{-1}$ in spring, but negative in winter ($0.16 \mathrm{~g} \mathrm{C} \mathrm{m}^{-2} \mathrm{day}^{-1}$ ) (fig. 5). The ratio between the Gross Primary Production (GPP) and respiration (R) was maximum in autumn (2.69) and minimum in winter (0.57). Although conclusions are still preliminary, differences in the ratio suggest a very different behaviour of the epilithic community during the two periods of the year, possibly related to the lower activity of the algal component of the community during winter.

Results are different in the siliceous tributary, La Major. This is a siliceous, well forested stream. Shaded reaches are colonized by conspicuous patches of the Rhodophycean Hildenbrandia rivularis, which is the most abundant component of the epilithic community during winter. In autumn and early spring this alga is partially covered by a thin diatom layer. NDM increased from winter $\left(0.24 \mathrm{~g} \mathrm{C} \mathrm{m}^{-2}\right.$

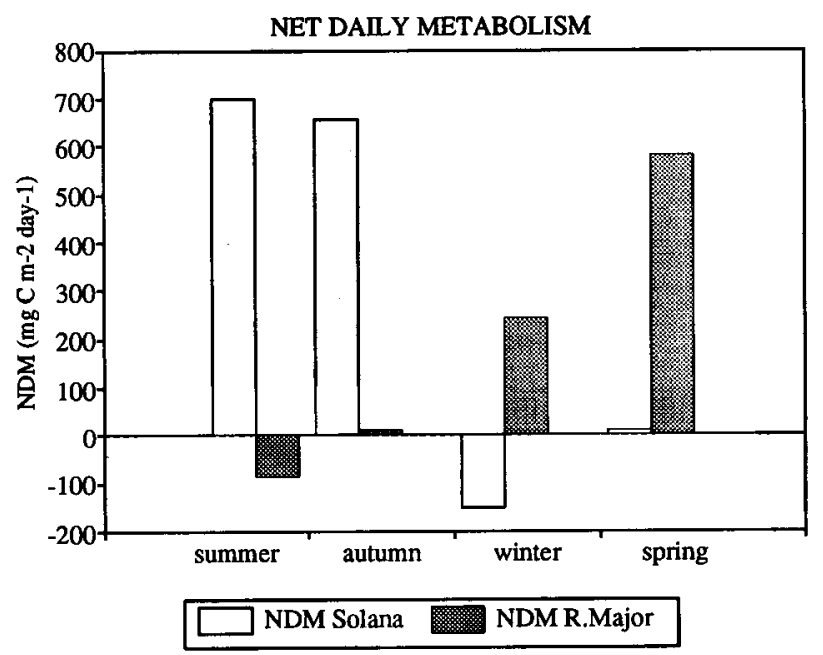

Figure 5. Values of net daily metabolism (in $\mathrm{g} \mathrm{C} \mathrm{m-2} \mathrm{day-1)} \mathrm{in} \mathrm{La}$ Major (siliceous) and La Solana (calcareous) streams during winter, spring and summer of the period 1990-1991. 


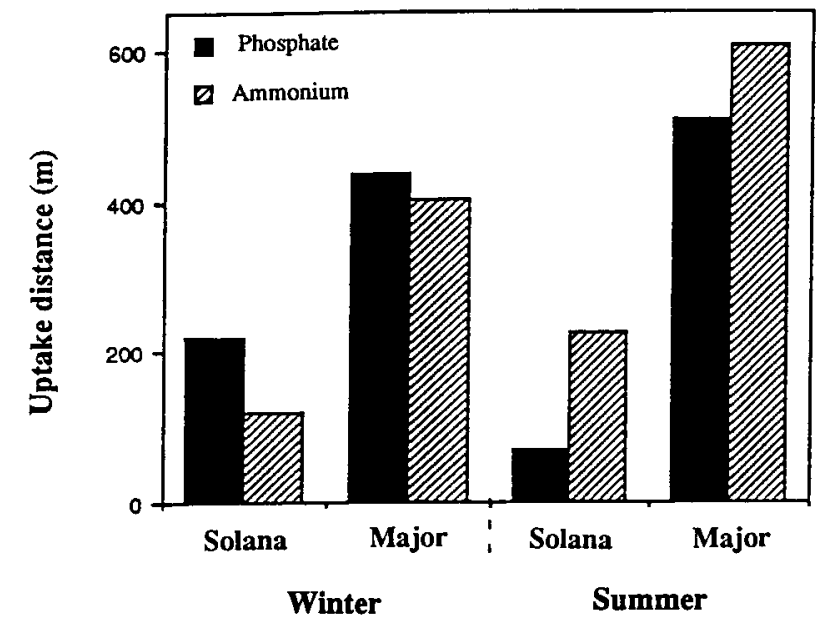

Figure 6. Uptake lengths for phosphorus and ammonium in La Major (siliceous) and La Solana (calcareous) streams during winter and summer 1990-1991.

day $\left.^{-1}\right)$ to spring $\left(0.6 \mathrm{~g} \mathrm{C} \mathrm{m}^{-2} \mathrm{day}^{-1}\right)$, but negative in summer $\left(-0.09 \mathrm{~g} \mathrm{C} \mathrm{m}^{-2}\right.$ day $\left.^{-1}\right)$ (fig. 5). The ratio GPP/R (1.47 in winter, 0.62 in autumn) reveals strong differences between the two periods, defining a converse situation to that of $\mathrm{La}$ Solana stream. In this stream canopy is absent during winter, but forest cover is dense during summer and early autumn. It may be assumed that light plays a key role in controlling the production and respiration processes in this stream.

\section{Nutrient dynamics in undisturbed tributaries}

Nutrient dynamics studies are being carried out by measuring uptake rates and lengths for phosphorus and ammonium within the two tributaries of the Ter River (La Solana and La Major) mentioned above. Our aim is to compare the cycling of these nutrients in different geological watershed features. Although both are 2nd order pristine streams and similar in local geomorphology, the main physical differences between the two are lithology and discharge regime. One is calcareous with discharges of $2-55 \mathrm{~m}^{3} / \mathrm{s}$, and the other is siliceous with $25-175 \mathrm{~m}^{3} / \mathrm{s}$. Biotic and abiotic uptake rates are measured in both streams following low-level nutrient releases of 45 to 120 minutes every month during 1990 - 1991 in two reaches $(40-100 \mathrm{~m}$ ) with different streambed morphology (one on cobble and gravel-riffles, and the other on rock outcrop). Nutrient additions are performed during the day and at night to elucidate the importance of the photosynthetic activity in relation to the bacterial activity.

The results are different in the two watersheds. The calca- reous stream appears to be more efficient in nutrient retention than the siliceous. Figure 6 shows differences in uptake lengths for the two nutrients during summer and winter. We have found that in calcareous reaches, lengths of phosphate uptake were shorter than ammonium in summer, possibly due to a coprecipitation of phosphate with $\mathrm{CaCO}_{3}$ during periods of high primary production. However, this behaviour is opposite in winter. In the siliceous watershed, nutrient uptake lengths are shorter in winter than in summer because of the well-developed canopy. Therefore, the differences between streams in nutrient dynamics could be related to environmental factors such as light and temperature.

We have also found noticeable differences between day and night uptake rates for the two elements. However, these differences depend on the season (summer or winter). The calcareous watershed showed seasonal differences in ammonium uptake rate. In winter this rate was higher during day than night. However, opposite pattern appeared in summer. On the other hand, phosphate uptake rates were higher during day than during night in both seasons; although the uptake rate a higher in summer than in winter. These differences in nutrient dynamics between phosphate and ammonium could be explained by the differential relative contribution of the algal and bacterial activity. Phosphate dynamics may be influenced by the algal community, while bacterial activity may play an important role in ammonium dynamics. The siliceous watershed only showed clear day and night differences in summer. The uptake rate were slightly higher during day for both nutrients.

\section{CONCLUSIONS AND PROSPECTIVE}

Although irregular discharges have a strong influence on the water chemistry (SABATER et al., 1991) and on the dynamics of benthic communities (SABATER \& SABATER 1988, PUIG et al., 1990) in the River Ter, the proper longitudinal organization of the river as an ecosystem is continually reset by topographic features and anthropogenic influences. The spatial structure of the river is a result of the natural processes occurring along a continuous gradient and the disturbances which affect them. Therefore, the composition and distribution of different biological assemblages living in the river must be the result of environmental conditions which reflect the structure and functioning of the river as an ecosystem (MARGALEF, 1983). In the Ter, the existence of reservoirs, local inputs of pollution, and irregular flow configures a patch dynamic structure (in the sense 


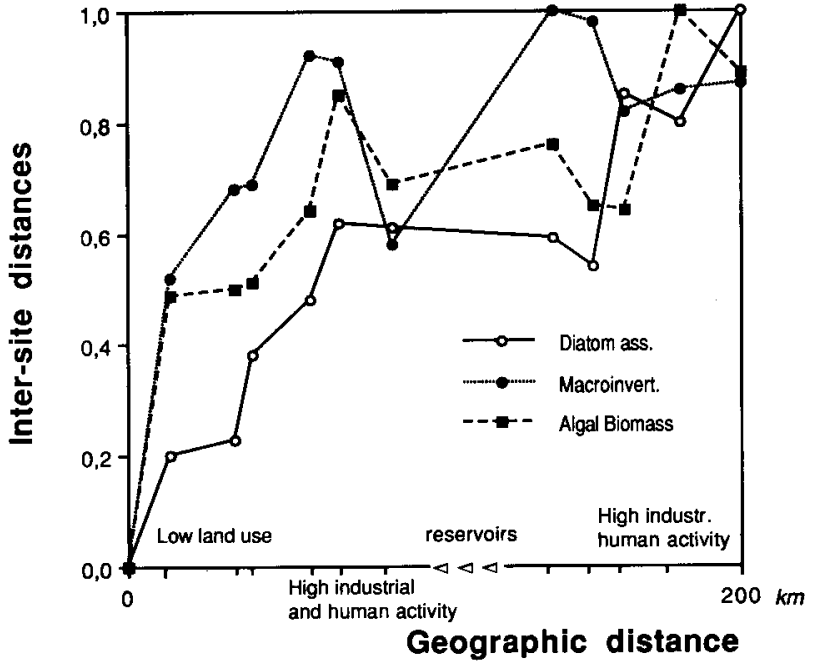

Figure 7. Inter-site distances of different groups of biological variables (diatom communities, macroinvertebrate assemblages, algal biomass) when plotted against geographical distances in the Ter.

proposed by TOWNSEND 1984 and PRINGLE et al., 1988) both in physico-chemical features (SABATER et al., 1990, 1991) and in organisms (SABATER et al., 1989; PUIG et al., 1990; SABATER \& SABATER, 1991).

Figure 7 provides a complete picture of the discontinuities on the biotic parameters related to the changes produced along the river, within the same reference scale, for comparing the different parameter derivatives. The assertion that any longitudinal change produced in abiotic or biotic parameters in rivers might also be a function of temporal variations (MARGALEF, 1960) is indicated in Mediterranean rivers, where flow is so variable. If we focus on the temporal changes of the chemical composition of the water, it is fairly evident that discharge fluctuation is the major factor involved (FISHER, 1983, SABATER et al., 1991). In the Ter, different environmental images of the longitudinal chemical features are obtained when each survey period is considered. During the periods of high discharge there are small differences in environmental features along the river. In contrast, during the low discharge periods the upstream sites and downstream sites are more divergent. A hyperbolic function shows that there will always be a minimum environmental distance at high discharges.

Temporal and spatial factors also operate with the distribution of organisms inhabiting the river. Benthic algal biomass in the Ter shows a distinctive longitudinal distribution when two favourable periods (spring and summer) for primary production are compared (SABA-
TER, 1989; SABATER \& SABATER, 1991). These both periods are similar with respect to the environmental conditions for algal growth (light availability, water temperature...), but water discharge is strikingly different, higher in spring and lower in summer. When both ecological images (spring and summer) of the river concerning algal biomass are compared, a clear distinction appears between. In spring, ecological differences between sites are relatively short (SABATER \& SABATER, 1991). It seems that high water discharge may act as an homogenizer of the environmental conditions and the behaviour of the primary producers. Chlorophyll- $a$ values in spring are independent of local nutrient increases. In summer chlorophyll- $a$ values are variable, being higher in those sites with higher nutrient concentrations. Lower discharge in summer favours local nutrient increases, thus enhancing benthic algae production.

In Mediterranean river systems, the hydrological annual pattern is usually modified by irregular climatic fluctuations that bring about sudden changes in their dynamics. Species are adapted to couple their biological cycles to temporal scales of variability of climatic events. As MARGALEF (1983) suggests, the organisms do their own Fourier analysis to foresee the environmental fluctuations. The spates act as huge inputs of external energy, which simplifies the structure of the river. Most of the organisms are carried down and the chemical composition of the water becomes more similar along the river. Therefore, floods are the main source of external energy invested in horizontal transport and mark the beginning of a new episode of a temporal pattern. In the Ter River, benthic algal vegetation was welladapted to the disturbances created by spates. After a catastrophic flood in November 1982, which washed away all the organisms, recovery of algal assemblages was achieved in a month. Although the recovery of the macroinvertebrate populations was slower, they reacted with a fast increase of diversity (PUIG et al., 1987).

In conclusion it is obvious that in Mediterranean systems, which are submitted to many diverse external influences, temporal and spatial variation are highly dependent. Both together reflect the capacity of the river to incorporate external energy (e.g.,spates) and to use it to adapt to the constantly changing environmental conditions.

In this context, recent research on the Ter has focused on functional aspects of undisturbed tributaries. The research is directed to two complementary objectives. One is focused in the metabolism of the epilithon, with special interest in the production process and the relative contribution of the 
algal and bacterial component. The second is the analysis of nutrient dynamics in the river under different environmental conditions (essentially light and substrata). Starting in undisturbed streams in order to evaluate the magnitude of the natural processes, our aim is to extend the approach to anthropogenically disturbed reaches of the river. Future research will also be directed to the specification of the role of the bacterial community in the processing both of allochthonous and autochthonous material in the river.

\section{ACKNOWLEDGEMENTS}

This research has been supported by the funding of the CICYT grants no 478-81 and NAT 89-0886. H. Guasch and E. Martí benefit a FPI grant to participate in the last project.

\section{REFERENCES}

ARMENGOL, J., SABATER,S., VIDAL, A. \& SABATER, F., 1991. Using the rescaled range analysis for the study of hydrological records: the River Ter as an example. Oecologia Aquatica, 10 (in press).

ARMITAGE, R.D., 1984. Environmental changes induced by stream regulation and their effect on lotic macroinvertebrate communities. In: A.Lillehammer and S.J.Saltveit (Editors), Regulat. Rivers. Universitesforlaget, Oslo, pp. 139-165.

BOTT, T.L., BROCK, J.T., CUSHING,C.E., GREGORY S.V., KING, D. \& PETERSEN, R.C., 1978. A comparison of methods for measuring primary productivity and community respiration in streams. Hydrobiologia, 60: 3-12.

BOTT, T.L., BROCK, J.T., DUNN, C.S., NAIMAN, R.J., OVINK, R.W. \& PETERSEN, R.C., 1985. Benthic community metabolism in four temperate stream systems: An interbiome comparison and evaluation of the river continuum concept. Hydrobiologia 123: 3-45.

CUMMINS, K.W., MINSHALL, G.W., SEDELL, J.R., CUSHING, C.E. \& PETERSEN, R.C., 1984. Stream ecosystem theory. Verh. Internat. Verein. Limnol., 22: 1818-1827.

CUSHING,C.E., 1988. Allochthonous detritus input to a small, cold desert spring-stream. Verh. Internat. Verein. Theor. Limnol., 23: 1107-1113.

FISHER, S.G., 1983. Succession in streams. In: J.R.Barnes \& G.W.Minshall (Editors), Stream ecology : application and testing of general ecological theory. Plenum Press, New York, pp.7-27.
LIKENS, G.E., BORMANN, F.H., PIERCE, R.S., EATON, J.S. \& JOHNSON, N.M., 1977. Biochemistry of a forested ecosystem. Springer, New York. 147pp.

MARGALEF, R., 1983. Limnologia. Omega, Barcelona. 1010pp.

MINSHALL, G.W., 1978. Autotrophy in stream ecosystems. Bioscience, 28: 767-771.

PEÑUELAS, J. \& SABATER, F., 1987. Distribution of macrophytes in relation to environmental factors in the Ter River, NE Spain. Internat. Rev. Gesamt. Hydrobiol., 72: 41-58.

PRAT, N., PUIG, M.A., GONZALEZ, G., TORT, M.I. \& ESTRADA, M., 1984. The Llobregat : a Mediterranean river fed by the Pyrenees. In: B.A.Whitton (Editor), The ecology of European Rivers. Studies in Ecology, Blackwell, London, pp.527-552.

PRINGLE, C.M., NAIMAN, R.J., BRETSCHKO, G., KARR, J.R., OSWOOD, M.W, WEBSTER, WELCOMME, R.L. \& WINTERBOURN, M.J., 1988. Patch dynamics in lotic systems : the stream as a mosaic. J. North Am. Benthol. Soc., 7: 503-524.

PUIG, M.A.,ARMENGOL, J., GONZALEZ, G., PEÑUELAS, J, SABATER, S. \& SABATER, F., 1987. Chemical and biological changes in the Ter River induced by a series of reservoirs. In: J.F.Craig and J.B.Kemper (Editors), Advances in regulated stream ecology. Plenum Press, New York, pp.373-382.

PUIG, M.A., GONZALEZ, G. \& RECASEN S,L., 1987a. Las comunidades de macroinvertebrados del río Ter, con especial referencia a Plecópteros, Efemerópteros, Tricópteros y Simúlidos. Limnetica 3: 125-132.

PUIG, M.A., ABOAL, M. \& SOSTOA, A., 1990. New approaches to Mediterranean fluvial communities. Oecologia Aquatica, 10 (in press).

RESH, V.H., BROWN, A.V., COVICH, A.P., GURTZ, M.E., LI,H.W., MINSHALL, G.W., REICE, S.R., SHELDON, A.L., WALLACE, J.B. \& WISSMA R,R., 1988. The role of disturbence theory in stream ecology. J. North Am. Benthol.Soc., 7: 433-445.

SABATER, F. 1987. On the interstitial Cladocera of the River Ter (Catalonia,NE Spain) with a description of the male of Alona phreatica. Hydrobiologia, 144: 51-62.

SABATER, F., 1988. The geochemical character of the River Ter watershed. Oecologia Aquatica, 9: 77-87.

SABATER, F. \& ARMENGOL,J., 1986. Chemical characterization of the Ter River. Limnetica, 2: 75-84.

SABATER, F. \& DE MANUEL,J., 1988. Interstitial isopoda of the Ter River (Catalonia,NE Spain) and description of two new species, Microcharon margalefi n.sp. and Proasellus phreaticus n.sp.. Stygologia, 4: 267-278. 
SABATER, F. \& VILA, P., 1990. The hyporheic zone considered as an ecotone. Oecologia Aquatica, 10 (in press).

SABATER, F., ARMENGOL, J. \& SABATER, S., 1989. Measuring discontinuities in the Ter River. Regul. Rivers, 3: $133-142$.

SABATER, F., SABATER, S. \& ARMENGOL, J., 1990. Chemical characteristics of a Mediterranean river basin as influenced by land uses in the watershed. Wat. Res., 24: 143-155.

SABATER, F., ARMENGOL, J. \& SABATER, S., 1991. Physico-chemical disturbances associated with spatial and temporal variation in a Mediterranean river. J. North Am. Benthol. Soc., 10: 2-13.

SABATER, S., 1988. Composicion y ciclo de pigmentos clorofilicos en las poblaciones del fitobentos del rio Ter durante un periodo de nueve meses. Oecologia Aquatica, 9: 61-75.

SABATER, S., 1989. Encrusting algal assemblages in a Mediterranean river basin. Arch. Hydrobiol., 114: 55-573.

SABATER, S., 1990a. Phytoplankton composition in a medium-sized Mediterranean river : the Ter (Spain). Limnetica, 6:47-56.

SABATER, S., 1990b. Composition and dynamics of a highly diverse diatom assemblage in a limestone stream. Hydrobiologia, 190: 43-53.
SABATER, S. \& SABATER, F., 1988. Diatom assemblages in a Mediterranean river basin. Arch. Hydrobiol., 111: 397-408.

SABATER, S. \& MUÑOZ, I., 1990. Successional dynamics of the phytoplankton in the lower part of the River Ebro. J. Plankton Res., 3: 573-592.

SABATER, S. \& SABATER, F., 1991. Longitudinal changes of benthic algal biomass in a Mediterranean river during two high production periods. Arch. Hydrobiol. (in press).

SABATER, S., SABATER, F. \& ARMENGOL, J., 1988. Relationships between diatom assemblages and physicochemical variables in the River Ter (NE, Spain). Internat. Rev. Gesamt. Hydrobiol., 73: 171-179.

TOWNSEND, C.R., 1984. The patch dynamics concept of stream community ecology. J. North Am. Benthol. Soc., 8: 36-50.

VANNOTE, R.L., G.W. MINSHALL, K.W. CUMMINS, J.R. SEDELL \& C.E. CUSHING. 1980. The river continuum concept. Can. Jour. Fish. Aquat. Sc. 37: 130-137.

WALLACE, J.B. \& MERRITT, R.W., 1980. Filter feeding ecology of aquatic insects. Annl. Rev. Entomol., 25: 103-132. 